\title{
Healthcare Financing in Rural Cameroon
}

\author{
Nathanael Ojong \\ Department of Social Science, York University, Keele St, Toronto, ON 4700, Canada; nojong@yorku.ca
}

Received: 2 October 2019; Accepted: 8 November 2019; Published: 12 November 2019

\begin{abstract}
In the global South, low-income populations are faced with frequent health shocks. Formal mechanisms to protect them against these shocks are absent or limited. Thus, what are the mechanisms used by low-income rural populations to finance healthcare? This paper draws on a qualitative study to examine the healthcare financing mechanisms of low-income rural populations in Cameroon. The findings suggest that low-income populations use 13 mechanisms to finance healthcare. Depending on several factors, people may use more than one of these mechanisms. In addition, social factors shape people's patterns of usage of these mechanisms. Patterns of usage of these mechanisms are embedded in the principle of reciprocity. The notion of reciprocity does seem to discourage people from enrolling in the limited voluntary health insurance programmes which exist in various communities. Newly insured people were more likely to drop out if they did not receive a payout.
\end{abstract}

Keywords: healthcare financing; rural health; micro health insurance; out-of-pocket payments; reciprocity; Cameroon

\section{Introduction}

Low-income populations-that is people living below national poverty lines-are exposed to numerous shocks. ${ }^{1}$ In fact, shocks are omnipresent among low-income populations in the global South [1]. Of all the risks faced by the poor, ill health often poses the greatest threat to their lives [2,3]. The mortality rate from illness and injury for adults below 60 is four times higher for women and two-and-a-half times higher for men in low-income countries than in high-income countries [4]. Several studies have highlighted the frequency of health shocks among the poor in the global South [5-7]. Health shocks are "unpredictable illnesses that diminish health status" [8] (p. 849). Uninsured health shocks are costly to individuals and households in terms of lost income and reduced consumption [9]. They lead not only to direct costs for medicine, treatment and transport, but also to indirect expenditures related to a reduction in labour supply and productivity $[10,11]$.

Health insurance programmes, aimed at giving low-income populations access to health services, are operational in several low-income communities in the global South [12-15], but subscription rates are low [16]. Countries are encouraged to adopt programmes aimed at ensuring universal health coverage, as it is built on the principle of equity [17] and may prioritise high-need groups [18]. However, due to budgetary constraints [11], just a few countries in the global South have adopted programmes aimed at ensuring universal health coverage [19-21]. Thus, in the global South, formal mechanisms to protect low-income populations against ill health are to a great extent absent or limited when available [22-25]. The absence of support is more visible in rural areas due to the discourse that constructs "rural as problematic, inferior and undesirable" [26] (p. 157). Therefore, low-income populations in rural areas often have to rely on out-of-pocket payments for healthcare.

1 In Cameroon, low-income populations are defined as those living below the national poverty line of 931 FCFA (1.5 USD) per day. The conversion rate used throughout this paper is 1 USD $=589$ FCFA (Franc Communauté Financière Africaine). 
Low-income populations have developed diverse mechanisms to finance healthcare, such as risk-share arrangements between close relatives [27-29], which are not limited by geographical boundaries and space [30]. Other risk-sharing arrangements occur through networks made up of households at the village level [31]. People also use donations from friends [5]. These arrangements function based on the principle of reciprocity in the sense of give-and-take [32,33]. Studies, including several conducted in Africa [5,34-37], provide crucial insights necessary to understand health issues in the different settings, including how low-income populations deal with ill health. However, these studies do not provide a comprehensive account of the different mechanisms used by low-income rural populations to finance healthcare. Additionally, these studies tend to focus on one mechanism used by the populations in the different contexts (e.g., [10,13,38,39]. Also, these studies do not show how social norms shape people's patterns of usage of the diverse healthcare financing mechanisms. Studies conducted in Cameroon mirror those in other geographical contexts. A recent study conducted in the country focused on gender and voluntary health insurance [40]. Another study examined the determinants of willingness to pay for a community-based prepaid healthcare system [41], while a recent study explored the role of supply-side factors in the occurrence of informal payments [42]. The question at the heart of this paper is therefore: What are the mechanisms used by low-income rural populations to finance healthcare?

This paper addresses this puzzle by analysing primary data collected in rural Cameroon in order to provide a detailed account of the mechanisms used by low-income populations to finance healthcare. We discuss how social norms shape people's use of the mechanisms. We analyse the tension between micro health insurance programmes and traditional risk-sharing arrangements.

The remainder of the paper is organised as follows. The next section provides the context of the study. We subsequently outline our research methodology. Attention then shifts to a presentation and discussion of our empirical findings.

\section{Context}

The public health sector is considered one of the driving forces of Cameroon's health system, due to its core objectives of preventing, improving and providing health services to its population. Public health facilities are organised into seven categories: general hospitals, central hospitals, regional hospitals, district hospitals, district medical centres, integrated health centres and ambulatory health centres [43]. To these, we add private clinics, health facilities operated by religious organisations and NGOs and, of course, traditional health institutions.

In 2013, communicable diseases (e.g., malaria, HIV/AIDS etc.) and non-communicable diseases, including road traffic accidents, accounted for $40.7 \%$ and $14.2 \%$ of the burden of disease, respectively [44]. In 2017, the causes of most deaths in the country were HIV/AIDS, malaria, lower respiratory infection, neonatal disorders, diarrheal diseases, ischemic heart disease, stroke, tuberculosis, road accidents, cirrhosis and congenital defects [44].

Public resources allocated to the health sector in Cameroon remain one of the lowest in Africa in terms of GDP [45]. Out of the US $\$ 61$ per Cameroonian spent on health in 2010, the government contributed only US $\$ 17$, which is $28 \%$ - of which US $\$ 8$ were provided by international donors [45]. Therefore, the cost of healthcare is largely borne by individuals through out-of-pocket payments. In 2015 , out of US\$156 per person spent on health in the country, US\$108 was out-of-pocket spending, US $\$ 23$ was government health spending, US\$20 was development assistance for health and US\$5 was prepaid private spending [46].

\section{Methodology}

This study focused on rural areas located in the North West region of Cameroon: Bafut, Mforya, Belo, Fundong, Fungom and Wum. The choice of the North West region for the study was also guided by the researchers' intention to benefit from their knowledge of the main languages and understanding of the sociocultural context. As the study aims to examine the diverse healthcare 
financing mechanisms used by low-income populations, including how social factors shape the use of these mechanisms, a qualitative study was preferred. We used interviews to generate in-depth description of the mechanisms used by low-income populations to finance healthcare. We focused on poor populations because we were particularly interested in investigating how they finance healthcare since they have a low and irregular income.

\subsection{Participants}

This study was conducted between 2011 and 2019. Some follow-up telephone interviews were conducted as the research progressed and additional information came to light, requiring us to go back and ask additional questions of the earlier participants. Research design in qualitative research remains flexible throughout the actual research [47].

Research participants had various characteristics (Table 1). As agrarian communities, most of them were engaged in agriculture (cultivation of yams, maize, vegetables, beans, plantains, coffee, ginger, groundnuts), beekeeping, fishkeeping and goat, pig and poultry farming. Others were engaged in petty trading (e.g., sale of roasted fish and plantains, cigarettes, sugar, biscuits, firewood, gasoline, fresh fish, corn beer, etc.), mobile street food service, sale of crushed stones, tailoring, sale of new and second-hand clothes, footwear, body lotion, kitchen utensils, bed sheets and covers etc. This context is important, as participants used income generated from these economic activities to finance healthcare. In total, 48 people were interviewed.

Table 1. Characteristics of participants.

\begin{tabular}{|c|c|c|}
\hline \multicolumn{2}{|c|}{ Characteristic } & \multirow{2}{*}{$\begin{array}{c}\text { Number of Research Participants } \\
29\end{array}$} \\
\hline Gender & Male & \\
\hline Ge & Female & 19 \\
\hline \multirow{4}{*}{ Marital Status } & Single & 8 \\
\hline & Married & 35 \\
\hline & Divorced & 1 \\
\hline & Widowed & 4 \\
\hline \multirow{4}{*}{ Age } & $20-35$ & 18 \\
\hline & $35-45$ & 13 \\
\hline & $45-55$ & 10 \\
\hline & $>55$ & 7 \\
\hline \multirow{4}{*}{ Level of education } & Primary & 26 \\
\hline & Secondary & 16 \\
\hline & University & 3 \\
\hline & No formal education & 3 \\
\hline
\end{tabular}

\subsection{Methods Adopted}

Prior to the start of data collection, we were in contact with a donor-funded organisation that runs microloan programmes in several impoverished communities in the country. The manager of this organisation facilitated access to their clients. We obtained permission from this organisation to interview their clients. Convenience sampling was used to recruit their clients for the interview. The organisation uses the group lending methodology-lending to self-selected groups of individuals who 
are jointly liable for a single loan [48] — to disburse loans to its clients. ${ }^{2}$ From each group, we selected individuals who were available and willing to have an interview. Additionally, snowball sampling was used to recruit people who were not clients of this organisation. Existing contacts were asked to nominate people known to them. We obtained informed consent from all research participants.

Interviews took place in English and Pidgin, but most interviews took place in Pidgin, the most commonly spoken local language. A translator was not needed as the researchers are originally from Cameroon and have lived in the region where the study was conducted. Interviews started with initial questions and then proceeded to follow-up probes, depending on the initial responses. This helped to ensure that the participant was not being influenced to respond in a particular way and confirmed that information gathered from participants mirrored the actual situation [49]. For confidentiality purposes, pseudonyms are used in this study and we do not disclose the identity of the organisations we worked with. Interviews were conducted in shops, stalls, houses and private areas at the premises of an organisation that grants microloans to low-income individuals. The interviews lasted no more than 90 minutes. An example of the interview prompts includes: Are you a member of a voluntary health insurance organisation? If the response was yes, we asked more specific follow-up questions, such as: Why did you enrol in the voluntary health insurance programme? If the response was no, we asked: Where did you get the money to pay your healthcare bill? Did you receive financial help from friends? Why? Did you receive financial help from family members? Depending on the responses, we asked more specific follow-up questions, such as: Do family members have an obligation to provide financial support when you are sick? Why? Depending on responses, we asked specific follow-up questions. The interviews were transcribed.

\subsection{Analysis Technique}

Our analysis explored themes in the responses of participants using a comparative method [50,51]. Data collected were sorted before analysis could begin. The sorting process meant interviews conducted in Pidgin were translated into English by the authors, and all interviews were transcribed. Sorting raw data into codes [52] made it possible to identify ideas that are divergent. Interviews were read several times and emerging concepts were grouped into categories using open coding [53] to develop first-order concepts. Wherever possible, we used participants' language to label in vivo codes. First-order concepts were subsequently categorised into second-order themes [54,55]. NVivo 11 assisted our analysis, enabling movement around free nodes and tree nodes, and within tree nodes [56]. We analysed the data by asking questions such as who, what, when, where and how, and by using theoretical memos $[53,56]$. The research was conducted in accordance with ethical principles such as respect for participants, no harm to participants, informed consent, voluntary participation, right to withdraw, avoidance of undue intrusion, preservation of anonymity, confidentiality of personal matters and data protection (The ethics approval was given by the manager of the organisation. We cannot provide the name of the organisation because it would be in violation of the terms of the approval).

\section{Results}

According to the findings, low-income populations in rural Cameroon use thirteen mechanisms to cover healthcare costs: savings, monetary gifts from relatives, monetary gifts from children, monetary gifts from friends, voluntary health insurance, loans from relatives, loans from neighbours and friends, loans from informal financial institutions (IFIs), business loans from microfinance institutions (MFIs), sale of assets, income from economic activity, provision of healthcare on credit and payment by instalment. These mechanisms fall under five core themes: loans, monetary gifts, personal resources, microinsurance and arrangements with healthcare institutions (Table 2).

2 For a detailed discussion of the group lending methodology, see [48]. 
Table 2. Major themes and corresponding finance mechanisms.

\begin{tabular}{|c|c|}
\hline Major Themes & Finance Mechanisms \\
\hline \multirow{4}{*}{ Loans } & Loans from relatives \\
\hline & Loans from friends \\
\hline & Loans from informal financial institutions \\
\hline & Loans from microfinance institutions \\
\hline \multirow{3}{*}{ Monetary gifts } & Monetary gifts from children \\
\hline & Monetary gifts from relatives \\
\hline & Monetary gifts from friends \\
\hline \multirow{3}{*}{ Personal resources } & Savings \\
\hline & Income \\
\hline & Sale of assets \\
\hline Microinsurance & voluntary health insurance \\
\hline \multirow{2}{*}{ Payment arrangement with healthcare institutions } & Payment by instalment \\
\hline & Provision of healthcare on credit \\
\hline
\end{tabular}

Source: Author's analysis based on field work.

\subsection{Loans}

Accounts of interviews indicate that low-income populations in rural Cameroon use loans from diverse sources to finance healthcare (Table 2). For instance, Mary, a mother of four, said: "I borrowed money from a family member because my child was sick, so I used the money to cover the hospital expenses." Others requested loans from friends and neighbours. When asked whether he borrows money from friends to cover healthcare expenses, Jude, a 34-year-old father of two, responded: "Yes, I borrow money from a friend and repay him later. I used 10,000 FCFA [17 USD] I borrowed from a friend to take care of my child who was sick." Along similar lines, Jason, a 53-year-old farmer, said: "I turn to my neighbour when I have financial difficulties. When my wife was sick, I explained the situation to him. He gave me a loan to deal with the situation and I repaid it later."

Participants take into consideration the economic situations of others before requesting a loan from them. For example, when asked whether he gets a loan from a relative or friends, Onana, a father of two, said: "It depends: a family member may be struggling to make ends meet [in such a scenario]. I prefer to borrow [money] from a friend than a family member."

When asked whether loans from friends, relatives and neighbours had to be repaid with interest, all participants insisted that loans from these sources were interest-free. For instance, Jane, a 39-year-old woman who sells fresh fish at the local market, said: "I do not repay the loan with interest when I get it from friends; I repay a loan with interest when I get it from njangis [informal financial institutions]."

As indicated by Jane, participants also used loans from informal financial institutions to finance healthcare. By informal financial institutions (IFIs), we refer to rotating savings and credit associations (ROSCAs) and accumulating savings and credit associations (ASCAs). ${ }^{3}$ As IFIs are pervasive in the country, it is easier to obtain a loan from these institutions, but these loans have to be repaid with interest, as noted by Ateba, a 36-year-old father of four who sells clothes at a local market:

3 ROSCAs are "associations in which members regularly contribute to a fund that is given in whole or in part to each contributor in turn" [57] (p. 11), while the ASCAs are associations in which members distribute part of the fund contributed as loans to members and members get their share of the fund at the end of the cycle. 
"When someone in my household is sick and I do not have money, I get a loan from the njangi [IFI] and use the loan to pay the medical bill. The loan has to be paid back with interest, but the interest is very low, that is, 10 FCFA [0.02] per 1000 FCFA [1.7 USD]."

Participants reported the tendency of using business loans provided by microfinance institutions (MFIs) to pay healthcare bills. In several cases, the business loan was used because it was provided during the period that the loan recipient or someone in their household was sick. For instance, Fabienne, a 48-year-old mother of six who sells basic foodstuff (such as rice, beans, plantains etc.) at a local market, said: "I fell sick during the period that I received my first loan [60,000 FCFA] [101 USD] and I was admitted at the hospital. So, I added the loan to the money I had to pay my hospital bill."

The use of business loans to pay medical bills was not restricted to men. Women equally used this mechanism, thus indicating the pivotal role they play in the household. For instance, when asked what she did with her business loan, Julie, a 46-year-old woman who sells corn beer, responded: "I used 20,000 FCFA [34 USD] to pay the hospital bill of my child who was in hospital. I also gave some money to my child who is in high school." The above quote shows that women take responsibility for meeting household expenses.

\subsection{Monetary Gifts}

Participants used monetary gifts from three sources—children, friends and relatives-to finance healthcare. Participants stressed the value of monetary gifts from relatives in times of sickness. For example, Refina, a 50-year-old mother of five, said: "I spent 150,000 FCFA [254 USD] for the medical bill of my child, who died of meningitis. Relatives gathered money and bought medicine. They provided financial assistance because they wanted her to be well."

The above statement shows that people view health emergencies as collective affairs, which require family members to pool their resources together to help kin in need. Participants insisted on the importance of sharing the healthcare costs among family members. For instance, David, a 34-year-old farmer, said: "When a person falls sick, we handle it collectively since we are our brother's keeper. So, we put our hands together. A relative was seriously sick and was at the General Hospital, so we all provided financial support and, thank God, he is well. Every person contributed the amount of money they could afford."

Participants also received monetary gifts from their children. For example, when asked where he gets money to pay his medical bills, Mbami, a 72-year-old father of 15, said: "money comes from the farm and my children. My children are grown-ups and are working, so they send me money when I need to go to the hospital."

Accounts of the interviews indicate that participants are of the view that their children have an obligation to take care of them, including paying their healthcare expenses, as expressed by Keith, a 70-year-old father of 11: "I'm an aged man. My children are now adults; I sent them to school. Well, that is to say that sometimes I depend on my children. They also help me by buying my medication." The above quote suggests that children have a "debt" to repay their parents. One way of repaying that debt is by paying the healthcare bills of their parents. Perhaps this explains why all participants declared that they received monetary gifts from their parents, and not loans.

Apart from the support provided by children, participants also used monetary gifts provided by friends to pay their medical bills. For instance, Jalili, a 54-year-old farmer, said: "When my child was sick, I received financial assistance from friends and neighbours. They helped me because it was a sad situation."

People associated financial assistance received from diverse sources with their ability to build social relationships with those in their communities. Participants emphasised the importance of establishing strong social relationships with members of their communities, as these relationships facilitate the flow of financial assistance in times of need. For example, when asked where she got the money to pay her medical bill, Eileen, a 46-year-old mother of five, said: "As you know, people 
cannot lack anything when they have a good social relationship with other people. I received financial support from people: I received money from friends and relatives."

\subsection{Personal Resources}

Although participants had access to financial assistance from diverse sources, they used their personal resources to cover their healthcare expenses when possible. For instance, Teresina, a 30-year-old mother of two who sells foodstuff at the local market, said: "when a person falls sick, I use the little money I get from the business to pay the expenses."

When money from income-generating activities was insufficient to cover healthcare costs, some participants sold their assets to meet the shortfall, as expressed by Ryan, a 54-year-old man who has four wives, 16 children and makes a living by selling firewood: "I get the money for hospital from the sale of firewood. I also sell goats to get money for the hospital."

As health shocks are unpredictable, participants indicated that they used their savings as a self-insurance device. For instance, Elodie, a 55-year-old mother of eight who runs a firewood business, said: "[it] comes from our savings, not our capital, because the business will fall if we use our capital." Participants saved money with MFIs and IFIs, and at home. In times of sickness they used their savings to cover the healthcare costs, as expressed by Jean-Pierre, a 48-year-old father of seven: "We save at the IFI which I said we save with. So, when a person falls sick, I withdraw some money and add to the money I get from the sale of sand, then I go to the microfinance institution and withdraw the money I saved there, since I saved the money to deal with illness."

The above quote shows that people tend to use multiple saving mechanisms simultaneously. The interviews indicate that simultaneous use of multiple savings was motivated by two major factors. First, it enabled people to manage risk. Participants noted that MFIs in the country have a record of closing down, causing their clients to lose their savings. Thus, in terms of savings, people avoid relying exclusively on MFIs. Second, the use of multiple saving mechanisms was one way of managing social relationships. Participants indicated that having one's savings in multiple institutions made it difficult for people to be aware of their financial standing; hence, one may not receive multiple requests for financial assistance from people in one's community.

\subsection{Microinsurance}

Some participants enrolled in voluntary health insurance schemes. As insured members, a significant percentage of their medical bill is paid by these institutions, as explained by Christina, a 33-year-old woman who sells foodstuff at a local market: "I don't like to be sick, so I like to prevent it. Here we have an organisation ... they pay $75 \%$ of the medical bill. Each year we register as a family for 15,000 FCFA [25 USD]. I prefer to pay 15,000 FCFA [25 USD] because, as members, when we go to the health centres around here we don't have to pay a deposit. After consultation, they [the health centre] give the bill and we pay just $25 \%$. So, I prefer to register and pay 15,000 FCFA [25 USD] to the organisation, then pay $25 \%$ for my medical bills. There are moments when my bill is more than 100,000 FCFA [169 USD]."

Accounts from the interviews indicate that some people are not familiar with the notion of risk-sharing as espoused by microinsurance institutions. For example, Edith, a 25 -year-old mother of one, said: "Three years ago, I became a member of the organisation and paid 19,000 FCFA [32 USD] for every person at home. No person was sick by end of that year, so I was discouraged and did not renew our membership the following year. But there were many sick cases in my family that year and I did not have money ... We spent almost 18,000 FCFA [30 USD] for a family member who had an accident. When he came back [home], my father, whom I know does not fall sick, wounded his hand while on the farm and we took him to the health centre. So, at the beginning of the following year, I decided to register everybody and paid the membership fee, but no person was sick. I'm confused. I'm not ready to renew my membership for next year." 


\subsection{Arrangements with Healthcare Institutions}

Participants reported that they received healthcare on credit when they had no money. Then, an arrangement was made with the relevant staff of the healthcare institution that provided the service for the bill to be paid later, when the funds were available. This was expressed by Dorothy, a 36-year-old mother of six: "I normally go to the health centre ... Sometimes the health centre treats me on credit, and I pay the bill later because they trust me. This happens when I don't have money." In a similar vein, Ndeh, a 32-year-old father of three, said: "we take the sick person to the health centre. When there is money, we use it. When there is no money, we negotiate with the chief of the health centre and we pay the bill later." The foregoing quotes underscore the vital role of trust in the relationship between people who require healthcare services and healthcare institutions.

Participants who could not pay the total healthcare bill when they checked out worked out a payment plan with the healthcare institution. For instance, Lucy, a 51-year-old mother of six, noted:

"One of my children had a problem with his appendix and required a lot of money. We had to pay 160,000 FCFA [271 USD] in order to have it removed, but we didn't have the money ... I have been paying the bill in instalments; I will soon finish paying it."

Again, this account underscores the role of trust in the relationship between healthcare institutions and their clients. The payment plan between Lucy and the healthcare institution may not have happened in the absence of trust, as contract enforcement institutions, in the country, are weak.

\section{Discussion}

The findings show that loans and monetary gifts are widely used to finance healthcare. Although both fall into two thematic areas, they are, however, based on the notion of reciprocity, in the sense of give-and-take [32,33]. In a reciprocity-based relationship, no person is a permanent lender. Individuals who lend money do so knowing that they will be borrowers in the future. Additionally, individuals who had received loans provide loans to their former lenders as a way of repaying the social debt they owe, although the "monetary" loan had been repaid. It is due to this notion of social debt that Shipton [58] argued that loans and repayments do not cancel each other out. Similarly, according to the principle of reciprocity, monetary gifts from relatives and friends have to be repaid when the occasion justifies. This is because a gift calls for a counter-gift [59]. The only uncertainty is related to the time when the gift will be repaid, but the gift will certainly be repaid. Thus, in a reciprocity-based environment, loans and monetary gifts from relatives and friends are viewed as debts. The findings, therefore, demonstrate that notions of reciprocity and debt are essential to understanding how low-income populations finance healthcare.

Arguably, it is also due to the principle of reciprocity that people received interest-free loans from family and friends. As people take turns as lenders and borrowers, it makes sense for people not to charge interest on loans given to one another. Again, according to the notion of reciprocity, people who provide interest-free loans have at one point been recipients of interest-free loans or will be recipients of interest-free loans in the future.

Additionally, due to a strong social relationship, a close friend approached for a loan may be uncomfortable asking the supplicant friend to pay interest on the loan, as it may mean that they are perhaps taking advantage of a desperate situation for economic gain. Charging interest on a loan may be viewed by people in these communities as not being sensitive to people's situations. Being sensitive to people's economic situations is part of the process of managing social relationships [60]. Additionally, it is against social norms in these local communities for people to charge interest on loans given to kin. According to social norms, people are expected to help those in their kin network and not make economic gains from them. This finding that people receive interest-free loans from relatives and friends is consistent with previous studies (e.g., $[1,61])$.

The concept of reciprocity is also applicable to the parent-children relationship. Parents take the position of "givers" by sending their children to school, ensuring that they learn a particular trade, and 
providing food for their nourishment as they grow, in addition to shelter and healthcare. Based on the foregoing, children have a "debt" to repay their parents, as in a reciprocal relationship no person is a permanent giver or receiver. When children become adults and have income-generating activities, they take the position of "givers", hence, they are expected to assist their parents in various ways, including paying their healthcare bills. This finding corroborates a study conducted in Ghana, which showed that parents expect their children to repay the debt they owe to them by fulfilling their responsibilities [62].

The principle of interdependence in the parent-child relationship is also embedded in the concept of reciprocity. Interdependence entails complementary relations between parties [63]. There is a complementary relationship between parents and their children, as each party takes turns in assisting the other in times of need. However, people do not rely on a single mechanism to finance healthcare.

It is already well-known that micro health insurance schemes, especially community-based health insurance programmes, seem quite effective in reaching a significant proportion of low-income populations who may otherwise have little or no financial protection against the cost of sickness $[13,16,38,39]$. However, of particular interest is how people's relationships with micro health insurance schemes are framed in terms of gains and losses. According to the findings, some members of voluntary health insurance schemes who did not make a claim in a year, because they or someone in their household was not sick, said that they lost money. Because they incurred a loss, they decided not to renew their insurance for the next year. In other words, whether people renew their subscription seems to depend on whether they perceive that they made a gain or loss. Their behaviour seems to align with a theory of decision making under uncertainty-prospect theory-that argues that individuals derive utility from gains and losses based on a reference point [64,65]. The fact that people did not renew their insurance because they did not make a claim suggests that they have a strong aversion to loss. They seem to gain more utility when their annual premium is not "lost". The behaviour of participants of voluntary health insurance schemes is not unique to Cameroon. Studies conducted in other countries show that several newly insured people have requested to get their premium back if they make no claims $[66,67]$. Additionally, our finding that people did not renew their contract when no payout occurred supports a previous study conducted in India that shows that lack of payouts led individuals to drop out of insurance schemes [68]. Moreover, our findings are consistent with other studies that show that people who receive a payout are more likely to renew their membership $[69,70]$.

Our finding that people did not renew their subscription when no payout occurred suggests a lack of understanding of the insurance concept whereby insurers use the pool of several premiums to pay for the losses of individuals who make claims. A possible explanation for this lack of understanding of the insurance concept is that the concept runs contrary to traditional risk-sharing mechanisms based on the principle of reciprocity [67]. According to this principle, there are no winners and losers, as people take turns in reaping the benefits of the arrangement. A person who helps another person by providing financial assistance to finance healthcare knows that the receiver of financial assistance will reciprocate when the need justifies. This is based on the notion that the assistance provided has to be obligatorily reciprocated.

\section{Conclusions}

Low-income populations in rural Cameroon are faced with frequent health shocks. With inadequate formal mechanisms to protect them against illness, they have developed numerous mechanisms to address their needs. Our findings suggest that they use thirteen mechanisms to finance healthcare. People tend to use the different mechanisms simultaneously in creative ways.

The use of these mechanisms is shaped by prevailing social norms in the local communities. It is precisely because of the social embeddedness of these mechanisms that monetary gifts are regarded as debts that must be repaid. Similarly, it is due to prevailing social norms that there remains an outstanding debt which must be repaid even after the repayment of a loan. It is as a result of the social construction of debt that monetary gifts received by parents from their children are viewed by the 
former as repayment of a debt. The articulation of the economic and social indicates that healthcare financing is not just about finance, it is also about managing social relationships.

As researchers of a qualitative study, we make no claim of generalizability. However, the study provides critical insight into the imaginative possibilities of low-income rural populations, including how social forces shape people's patterns of usage of healthcare financing mechanisms.

Funding: The APC was funded by York University.

Acknowledgments: We are grateful to the editor and two anonymous reviewers for extensive comments and suggestions as this article gradually came to fruition. All remaining shortcomings are solely our own.

Conflicts of Interest: The author declares no conflict of interest.

\section{References}

1. Collins, D.; Morduch, J.; Rutherford, S.; Ruthven, O. Portfolios of the Poor: How the World's Poor Live on \$2 a Day; Princeton University Press: Princeton, NJ, USA, 2009.

2. Ahmed, S.; Mbaisi, J.; Moko, D.; Ngonzi, A. Health is wealth: How low-income people finance health care. J. Int. Dev. 2005, 17, 388-396. [CrossRef]

3. Jutting, J. Do Community-based Health Insurance Schemes Improve Poor People's Access to Health Care? Evidence from Rural Senegal. World Dev. 2004, 32, 273-288. [CrossRef]

4. World Bank. World Development Report: Risk and Opportunity—Managing Risk for Development; World Bank: Washington, DC, USA, 2014.

5. Bonfrer, I.; Gustafsson-Wright, E. Health shocks, coping strategies and foregone healthcare among agricultural households in Kenya. Glob. Public Health 2017, 12, 1369-1390. [CrossRef] [PubMed]

6. Gertler, P.; Gruber, J. Insuring consumption against illness. Am. Econ. Rev. 2002, 92, 51-70. [CrossRef] [PubMed]

7. Wagstaff, A.; Lindelow, M. Are Health Shocks Different? Evidence from a Multi-Shock Survey in LAOS; World Bank Policy Research Working Paper 5335; World Bank: Washington, DC, USA, 2010; pp. 1-38.

8. Leive, A.; $\mathrm{Xu}, \mathrm{K}$. Coping with out-of-pocket health payments: Empirical evidence from 15 African countries. Bull. World Health Org. 2008, 86, 849-856. [CrossRef] [PubMed]

9. Dercon, S.; Hoddinott, J.; Woldehanna, T. Consumption and shocks in 15 Ethiopian villages, 1999-2004. J. Afr. Econ. 2005, 14, 559-585. [CrossRef]

10. Asfaw, A. Cost of Illness, Demand for Medical Care, and the Prospect of Community Health Insurance Schemes in the Rural Areas of Ethiopia; Peter Lang Publishing: Frankfurt, Germany, 2003.

11. World Bank. Universal Health Coverage (UHC) in Africa: A Framework for Action: Main Report; World Bank: Washington, DC, USA, 2016.

12. Chemouni, B. The political path to universal health coverage: Power, ideas and community-based health insurance in Rwanda. World Dev. 2018, 106, 87-98. [CrossRef]

13. Dror, D.; Jacquier, C. Micro-insurance: Extending Health Insurance to the Excluded. Int. Soc. Sec. Rev. 1999, 52, 71-97. [CrossRef]

14. Lu, C.; Mejía-Guevara, I.; Hill, K.; Farmer, P.; Subramanian, S.; Binagwaho, A. Community-Based Health Financing and Child Stunting in Rural Rwanda. Am. J. Public Health 2016, 106, 49-55. [CrossRef] [PubMed]

15. Mebratie, A.; Sparrow, R.; Yilma, Z.; Alemu, G.; Bedi, A. Enrolment in Ethiopia's Community-Based Health Insurance Scheme. World Dev. 2015, 74, 58-76. [CrossRef]

16. Platteau, J.-P.; De Bock, O.; Gelade, W. The Demand for Microinsurance: A Literature Review. World Dev. 2017, 94, 139-156. [CrossRef]

17. United Nations. Transforming Our World: The 2030 Agenda for Sustainable Development; United Nations: New York, NY, USA, 2015.

18. Witter, S.; Govender, V.; Ravindran, S.; Yates, R. Minding the gaps: Health financing, universal health coverage and gender. Health Policy Plan. 2017, 32, 4-12. [CrossRef] [PubMed]

19. Parmar, D.; De Allegri, M.; Savadogo, G.; Sauerborn, R. Do community-based health insurance schemes fulfil the promise of equity? A study from Burkina Faso. Health Policy Plan. 2014, 29, 76-84. [CrossRef] [PubMed]

20. Wagstaff, A.; Nguyen, H.; Dao, H.; Bales, S. Encouraging health insurance for the informal sector: A cluster randomized experiment in Vietnam. Health Econ. 2016, 25, 663-674. [CrossRef] [PubMed] 
21. Atun, R.; de Andrade, L.; Almeida, G.; Dmytraczenko, T.; Frenz, P.; Garcia, P.; Gómez-Dantés, O.; Knaul, F.M.; Muntaner, C.; de Paula, J.B.; et al. Health-system reform and universal health coverage in Latin America. Lancet 2015, 385, 1230-1247. [CrossRef]

22. De Allegri, M.; Sauerborn, R.; Kouyaté, B.; Flessa, S. Community health insurance in sub-Saharan Africa: What operational difficulties hamper its successful development? Trop. Med. Int. Health 2009, 14, 586-596. [CrossRef] [PubMed]

23. Grimm, M. Mortality shocks and survivors' consumption growth. Oxf. Bull. Econ. Stat. 2010, 72, $146-171$. [CrossRef]

24. Mathauer, I.; Schmidt, J.; Wenyaa, M. Extending social health insurance to the informal sector in Kenya. An assessment of factors affecting demand. Int. J. Health Plan. Manag. 2008, 23, 51-68. [CrossRef] [PubMed]

25. Tirivayi, N.; Knowles, M.; Davis, B. The Interaction between Social Protection and Agriculture; Food and Agriculture Organization of the United Nations: Rome, Italy, 2013.

26. Malatzky, C.; Bourke, L. Re-producing rural health: Challenging dominant discourses and the manifestations of power. J. Rural Stud. 2016, 45, 157-164. [CrossRef]

27. Lucas, R.; Stark, O. Motivations to remit: Evidence from Botswana. J. Pol. Econ. 1985, 93, 901-918.

28. Lund, S. Informal Credit and Risk-Sharing Networks in the Rural Philippines. Ph.D. Thesis, Food Research Institute, Stanford University, Stanford, CA, USA, 1996.

29. Fafchamps, M.; Gubert, F. The Formation of Risk Sharing Networks. J. Dev. Econ. 2007, 83, 326-350. [CrossRef]

30. Mazzucato, V. Informal insurance arrangements in Ghanaian migrants' transnational networks: The role of reverse remittances and geographic proximity. World Dev. 2009, 37, 1105-1115. [CrossRef]

31. De Weerdt, J.; Dercon, S. Risk-sharing networks and insurance against illness. J. Dev. Econ. 2006, 81, 337-356. [CrossRef]

32. Hann, C. The gift and reciprocity: Perspectives from economic anthropology. In Handbook of the Economics of Giving, Altruism and Reciprocity; Ythier, J., Kolm, S.-C., Eds.; Elsevier: Amsterdam, The Netherlands, 2006; pp. 207-223.

33. Shipton, P. The Nature of Entrustment: Intimacy, Exchange and the Sacred in Africa; Yale University Press: New Haven, CT, USA, 2007.

34. Mkandawire, P.; Macpherson, K.; Madut, K.; Ataric, O.; Rishworthd, A.; Luginaahe, I. Men's perceptions of women's reproductive health in South Sudan. Health Place 2019, 58, 102157. [CrossRef] [PubMed]

35. Neely, A.; Ponshunmugam, A. A qualitative approach to examining health care access in rural South Africa. Soc. Sci. Med. 2019, 230, 214-221. [CrossRef] [PubMed]

36. Novignon, J.; Lawanson, A. Health expenditure and child outcomes in sub-Saharan Africa. Afr. Rev. Econ. Financ. 2017, 9, 96-121.

37. Witter, S.; Boukhalfa, C.; Cresswell, J.; Daou, Z.; Filippi, V.; Ganaba, R.; Goufodji, S.; Lange, I.L.; Marchal, B.; Richard, F.; et al. Cost and impact of policies to remove and reduce fees for obstetric care in Benin, Burkina Faso, Mali and Morocco. Int. J. Equity Health 2016, 15, 123. [CrossRef] [PubMed]

38. Liu, K.; Cook, B.; Lu, C. Health inequality and community-based health insurance: A case study of rural Rwanda with repeated cross-sectional data. Int. J. Public Health 2019, 64, 7-14. [CrossRef] [PubMed]

39. Mebratie, A.; Sparrow, R.; Yilma, Z.; Abebaw, D.; Alemu, G.; Bedi, A. The impact of Ethiopia's pilot community-based health insurance scheme on healthcare utilization and cost of care. Soc. Sci. Med. 2019, 220, 112-119. [CrossRef] [PubMed]

40. Oraro, T.; Ngube, N.; Atohmbom, G.; Srivastava, S.; Wyss, K. The influence of gender and household headship on voluntary health insurance: The case of North-West Cameroon. Health Policy Plan. 2018, 33, 163-170. [CrossRef] [PubMed]

41. Donfouet, H.; Makaudze, E.; Mahieu, P.; Malin, E. The determinants of the willingness-to-pay for community-based prepayment scheme in rural Cameroon. Int. J. Health Care Financ. Econ. 2011, 11, 209-220. [CrossRef] [PubMed]

42. Kankeu, H.; Boyer, S.; Fodjo Toukam, R.; Abu-Zaineh, M. How do supply-side factors influence informal payments for healthcare? The case of HIV patients in Cameroon. Int. J. Health Plan. Manag. 2016, 31, E41-E57. [CrossRef] [PubMed]

43. Ministry of Public Health. Health Analytical Profile, Cameroon; Ministry of Public Health: Yaoundé, Cameroon, 2017. 
44. Global Burden of Disease. Country Profile. 2013. Available online: http://www.healthdata.org/cameroon (accessed on 20 June 2019).

45. World Bank. Cameroon Economic Update. Towards Greater Equity; World Bank: Washington, DC, USA, 2013.

46. Institute for Health Metrics and Evaluation. Financing Global Health; Institute for Health Metrics and Evaluation: Seattle, WA, USA, 2017; Available online: http://www.healthdata.org/ (accessed on 20 June 2019).

47. Taylor, S.; Bogdan, R.; DeValt, M. Introduction to Qualitative Research Methods; John Wiley: New York, NY, USA, 2016.

48. Armendariz, B.; Morduch, J. The Economics of Microfinance; MIT Press: Boston, MA, USA, 2010.

49. Jack, S. The role, use and activation of strong and weak network ties: A qualitative analysis. J. Manag. Stud. 2005, 42, 1233-1259. [CrossRef]

50. Glaser, B. Theoretical Sensitivity; The Sociological Press: Mill Valley, CA, USA, 1978.

51. Silverman, D. Doing Qualitative Research: A Practical Handbook; Sage: London, UK, 2010.

52. Eisenhardt, K. Better Stories and Better Constructs: The Case for Rigour and Comparative Logic. Acad. Manag. Rev. 1989, 16, 620-627. [CrossRef]

53. Corbin, J.; Strauss, A. Basics of Qualitative Research: Techniques and Procedures for Developing Grounded Theory; Sage: Los Angeles, CA, USA, 2008.

54. Corley, G.; Gioia, A. Identity Ambiguity and Change in the Wake of a Corporate Spin-off. Adm. Sci. Q. 2004, 49, 173-208.

55. Pratt, M. From the Editors: For the Lack of a Boilerplate: Tips on Writing up (and Reviewing) Qualitative Research. Acad. Manag. J. 2009, 52, 856-862. [CrossRef]

56. Bazeley, P. Qualitative Data Analysis with NVivo; Sage Publication: London, UK, 2007.

57. Ardener, S. Microcredit, Money Transfers, Women, and the Cameroon Diaspora. Afr. Focus 2010, $23,1-24$. [CrossRef]

58. Shipton, P. Credit between Cultures; Yale University Press: New Haven, CT, USA, 2010.

59. Mauss, M. The Gift: Forms and Functions of Exchange in Archaic Societies; Cohen \& West: London, UK, 1966.

60. Nelson, M. Single mothers and social support: The commitment to, and retreat from, reciprocity. Qual. Sociol. 2000, 23, 291-317. [CrossRef]

61. Ojong, N. Informal borrowing sources and uses: Insights from Cameroon. Third World Q. 2019, 40, 1730-1749. [CrossRef]

62. Twum-Danso, A. Reciprocity, Respect and Responsibility: The 3Rs Underlying Parent-Child Relationships in Ghana and the Implications for Children's Rights. Int. J. Child. Rights 2009, 17, 415-432. [CrossRef]

63. Servet, J.-M. Le principe de réciprocité chez Karl Polanyi. Contribution à une définition de l'économie solidaire. Rev. Tiers Monde 2007, 190, 255-273. [CrossRef]

64. Kahneman, D.; Tversky, A. Prospect Theory: An Analysis of Decision under Risk. Econometrica 1979, 47, 263-291. [CrossRef]

65. Tversky, A.; Kahneman, D. Advances in prospect theory: Cumulative representation of uncertainty. J. Risk Uncertain. 1992, 5, 297-323. [CrossRef]

66. Basaza, R.; Criel, B.; Van der Stuyft, P. Community health insurance in Uganda: Why does enrolment remain low? A view from beneath. Health Policy 2008, 87, 172-184. [CrossRef] [PubMed]

67. Platteau, J.-P. Mutual insurance as an elusive concept in traditional rural communities. J. Dev. Stud. 1997, 33, 764-796. [CrossRef]

68. Platteau, J.-P.; Ugarte, D. Understanding and Information Failures: Lessons from a Health Microinsurance Program in India; CRED Working Papers; University of Namur: Namur, Belgium, 2016.

69. Fitzpatrick, A.; Magnoni, B.; Thornton, R. Microinsurance Utilization in Utilization in Nicaragua: A Report on Effects on Children, Retention, and Health; ILO Microinsurance Innovation Facility Research Research Paper No 5; International Labour Organisation: Geneva, Switzerland, 2011.

70. Dong, H.; De Allegri, M.; Gnawali, D.; Souares, A.; Sauerborn, R. Drop-out analysis of community-based health insurance membership at Nouna, Burkina Faso. Health Policy 2009, 92, 174-179. [CrossRef] [PubMed] 